\title{
Creative Teaching Methods for Developing Reading Literacy in Teaching Process
}

\section{Abstract}

Reading a text is very important at any age in any sphere of life. Some children have serious problems in reading and sometimes they are encouraged to read more and faster in order to prove the quality of their reading skills, however, rate and understanding do not always correlate.

Skills to understand and analyse the text are of primary importance in reading process. Usually the first reading experience is acquired during elementary school when children master their basic reading skills and form their attitude to reading.

Skills to understand the text is one of the basic requirements for successful study process. Understanding of the text and reading skills do not only mean relating the text to spoken words and merging letters in words; they also imply skills to understand, analyse and evaluate the written text.

The aim of the study is to analyse creative teaching methods of reading literacy in pedagogical process and to make recommendations for adults to improve children's reading skills.

Materials and methods include an analysis of literature on pedagogy and psychology of Latvia and abroad.

Literature analysis reflects different methods that can be used in pedagogical process to train reading skills by exercising various activities and resources. Literacy and especially understanding of the text is directly influenced by the environment where the child lives and learns, as well as educational systems, traditions, opportunities and personal goals.

The article analyses reading problems for individuals with dyslexia or reading disabilities. Children with dyslexia have difficulties in understanding the correlation between the letter and the sound and merge letters together to form a word. These children need individual approach to training reading skills.

Different strategies can be used to improve the understanding of the text and in that way raise literacy of children in general. The principle of creativity serves as a reliable basis of creative methods. There are different creative methods of teaching literacy which can be used in pedagogical process in order to train children reading skills by exercising different activities and resources. The main methods are "READS" method, "CAPS" method and "KWL" strategy.

Key words: reading literacy, methods of teaching reading skills, reading strategies 


\section{Introduction}

Comprehension of written texts is significant in every sphere of life and at every age. At the beginning of schooling when children acquire reading skills, they are often encouraged to read more and faster in order to prove high quality of their reading skills. However, the speed and comprehension do not always go hand in hand.

The ability to understand, analyse and use the information that has been read later on during the learning process is significant both for learning school subjects and for various purposes in other stages of life. Children start to acquire the basic readings skills from early childhood. They do it mechanically by copying and memorising; it is only in later stages of learning that they engage themselves in conscious reading activities to understand the content of the text. Children gain the first reading experience in primary school, and by the fourth year of schooling the basic reading skills and attitude towards reading are established.

The ability to understand what has been read provides one of the most significant foundations for a successful schooling process. Reading literacy and reading comprehension are not only abilities to connect a written text with oral utterances and join letters in words. They are abilities to perceive, understand and assess a written text. It is especially important when children change grades moving from Grade 4 to 5; they no longer learn to read but have to start reading in order to learn.

\section{Aim of the study}

The aim of the study is to analyse creative reading literacy teaching methods in teaching process and offer suggestions to teachers and parents for improving children's reading literacy.

\section{Materials and methods}

Materials and methods include an analysis of pedagogic literature written by Latvian and foreign teachers and psychologists.

In the course of educational process the volume of information increases, and so does the necessity to read and comprehend; simultaneously the number of children and young people who experience difficulties in this respect also increases. However, almost all school subjects and therefore the level of academic success directly depend on the comprehension of the texts read and the overall attitude towards reading. Difficulties in text comprehension may be connected with drawbacks of the teaching process and motivation, as well as insufficient intellectual development and various reading disorders.

B. Hurrelmann et al consider that the aim of learning and reading literacy activities is to teach the student to read independently, to understand the meaning of the text focusing attention on the plot. Thus, reading means both learning to read and reading to learn. Children live in a social environment where their language skills and later reading skills are affected by various factors of the environment (Hurrelmann et al 1993). 
Every child is part of a complex language environment of his/her parents and the surrounding culture. In most cases the learning process proceeds indiscernibly: children meet people who speak the language, they learn the vocabulary of the spoken language and gradually engage themselves in dialogues with other people, thus beginning the process of verbal communication. Biological factors and factors related to the experience gained play a significant role in the process of learning and developing a language (Woolfolk, 2008).

Children have mastered the basics of their mother tongue by the time they go to school. Small children can understand the meaning of complicated words of their native language; however, in their own speech they prefer using relatively simple words. More complicated words and expressions are used when children's level of education rises (Rathus, 1988).

To develop reading skills, various teaching methods and techniques are used, and various types of activities, resources and structuring of the text are chosen. The primary in this respect are: the environment in which the child lives and learns, the goals of different education systems, personal aims, traditions and social possibilities that directly affect reading literacy and especially the comprehension of the text.

A significant precondition for acquiring reading literacy is an educated environment, good and correct language that forms the overall language experience and later on becomes a decisive factor.

Reading is a process of extracting the meaning from the text. In the process of learning to read several skills are necessary: recognition of letters, joining of letters into syllables, phonetic perception etc. In order to read and understand the text, the following is necessary:

1. to learn to decode and read a published text,

2. to comprehend the meaning of what has been written.

There is a close connection between learning to read, linguistic understanding, and the ability to reflect the spoken language. In the process of learning to read also the level of phonological comprehension is important.

Phonological comprehension characterises children's ability to analyse the sound structure, i.e. differentiate speech sounds whereas the understanding of phonemes is the ability to become aware of and understand separate phonemes (Tūbele, 2008).

In the process of reading visual perception acts first; afterwards children compare the image with oral speech and only then comprehend the meaning.

Language is a system of symbols that forms the basis of the symbolic representation of the world in psyche. Symbols are words that correspond to various events, situations and actions of the real world (Kintsch et al, 1978).

Comprehension of the text is influenced by life experience related to a person's belonging to a certain gender, class, ethnicity, sexual orientation, physical health, etc. Difficulties in comprehending the text may be signs of dyslexia or reading 
disorders. Comprehension of the text includes the ability to understand and use the written form of language as well as to understand texts of various difficulty levels that require the knowledge of new information and literary experience gained through reading (Lerner, 1997).

Reading is part of our culture, therefore work with the text is of special importance for the perception and processing of information. Work with the text is a complex objective that includes the ability to find, memorise and summarize information.

In order readers can understand the meaning of the text they

1) have to be able to recognise the meaningful units (morphemes) in the text,

2) use certain rules that determine the sequence and design of morphemes (Artelt, 2001).

Every sentence contains two main structure components: syntax and semantics. Syntax characterises the form and structure of symbols that form sentences. Language can be understood if its basic units are combined in a certain definite way. By combining words randomly, senseless combinations are formed that bear no meaning of their own (Nunes et al., 2009).

To achieve reading comprehension, an early and successive learning process that matches the child's abilities is indispensable. When learning to read, children use a simple coding skill - they memorise the written letter and learn how to pronounce it. Afterwards they try to imagine what letters look like and how they are pronounced when they form words. When learning and remembering words and their meanings, a letter is associated with a sound to form syllables and words. However, if dyslectic symptoms or reading difficulties appear, this process turns out to be formidable and reading comprehension therefore becomes problematic. In such cases children (and adults if they have a similar disorder) experience difficulties in understanding the link between the sound and the letter. If children need too much time to read the word, it becomes hard to read and understand the entire sentence. While reading longer sentences or paragraphs, children may forget particular words and their meanings (Anderson, 1995; Rosser, 1994).

Reading comprehension difficulties occur while studying various subjects (for instance, a foreign language) when the slow speed interferes with the acquisition of knowledge in other subjects as it is impossible to acquire knowledge or write things down within the given time limit; in order to compensate for that, children learn texts by heart. Therefore insufficient comprehension of the text can lead to a considerably limited productivity of the entire learning process.

According to J. Das there are various strategies that can be used to improve the comprehension of the text and thus develop the overall reading literacy. It is particularly teaching mastery and the teacher's personal model that encourage children to apply the newly learnt cognitive methods and techniques. Multisensory methods are considered to be the basis for creative methods that are based on the recognition of words, explanation, comprehension and the principle of innovation, 
in such a way integrating the overall language process: reading, speaking, listening and writing create a dynamic model of lifelong learning (Das, 1998).

R. Davis singles out the following basic principles on which psychological assistance and correction are based:

- Mutual respect and trust, belief that the problem can have a positive solution

- Cooperation

- Awareness of disorientation

- Emotional discharge

- Change of the habitual reading comprehension and perception stereotypes

- Orienting consulting using methods that regulate orientation disorders thus lessening symptoms of reading difficulties (Davis, 1997).

For a better understanding of the text, sometimes thinking in symbols and words is necessary, yet it can cause confusion and disorientation. Symbols are part of written information that are often used without understanding their meaning as no image of the word or symbol is forming in the mind. Until the moment when the person understands the words help cannot be offered. It is difficult to learn words that cause disorientation. They can make children forget everything they wanted to learn. When a denomination for words and symbols is found, it is possible to eliminate disorientation (and simultaneously the symptom of reading difficulties).

In order to solve the above mentioned problems, the creative work method called "Orienting consulting" is used (Davis, 1997; Friend et al, 1996). From the point of view of teachers and physiologists the conception of "orienting" is also seen as the conception of "attention". Orienting consulting ensures support for focussing attention. It considerably reduces disorientation and disorders in the course of reading, work with words, writing, conversation and mathematical calculations. As a result of concentrating attention a sense of "control" is formed. It is necessary to acquire control and the ability to take responsibility for a personal learning system that is important for the entire learning process and especially for such a complicated system as reading. Its result is precise perception of reality that includes comprehension of written words.

In this process, all senses are used foreseeing their integrated conception in order to grasp and discuss the information received. Multisensory approach provides stimuli for the brain centres necessary for its operation ensuring permanent memorisation.

During the course of orienting consultation"Learning of symbols"takes place: a person learns to think non-verbally using form words. During the process of learning of symbols children acquire the structure of letters and their interconnectedness in a word. Also the understanding of form words is deepened, for instance, children learn to discriminate between the meanings of such conjunctions as "and", "but" and "yet". Thus, the formation of notions takes place, and creativity is used in the 
learning process by forming thought images for the "stimulation" words (form words), in such a way creating symbol images that illustrate the meaning of words that are followed by an image created by them (Peterson et al, 2002; Plucker et al, 2004).

In order to achieve the comprehension of the text, enriched learning environment should be considered and all processes connected with reading have to be improved:

- Speech

- Pronunciation of long words

- Learning of the alphabet, weekdays, colours, shapes, numbers

- Learning to understand the connection between letters and sounds, etc.

An enriched learning environment secures emotional and psychological support that in its turn creates the feeling of security and additional positive stimuli during the learning process. When children act in an enriched learning environment, the neuron activity increases (Skola visiem, 2002).

\section{Results}

Analysis of pedagogical literature has given an opportunity to get acquainted with contemporary methods, strategies and theories for teaching reading in Latvia and abroad.

Questions like how to teach to read and what are the best ways have been topical in every stage of development of the pedagogical thought. It is not significant to teach letters mechanically; what matters is the ability and skill to understand what has been read and the possibilities for using daily reading skills.

The content of teaching how to read and the choice of teaching methods depend on children's psychological and physiological peculiarities as well as those of the native language, teaching aims, language peculiarities, teaching skills and education system guidelines.

Theories for Teaching Reading and Writing:

- Approach to decoding - indicates that the $A B C$ book begins with separate letters, language sounds and moves towards the decoding of words and sentences.

- Linguistic approach - while learning to read, reading comprehension is important; in order to understand the texts read, prior knowledge about the language and the plot of the text are necessary.

- Theory of entirety - learning to read and write is based on the students' prior knowledge about the outer world and simultaneous learning of the decoding skill, broadening the vocabulary, emphasising the experience and comprehending the text (Корнев, 2003). 
Teaching Methods for Reading and Writing Skills:

- Analytic-synthetic harmonization method: reading and writing skills have to be developed simultaneously. Initially, a notion must be created that the basic unit of language is the word that can be divided into syllables; words are comprised of sounds and sounds can be differentiated in a word. When learning to read, special attention has to be paid to reading in syllables.

- Perfected analytic-synthetic harmonization method: while learning to read, each sound is listened to in a word and their sequence is established, sounds are differentiated, they are associated with letters and their correspondence is established which results in correct and conscious reading.

- Phonetic methods: emphasis on the relations between the sound and the letter; it is important to read fluently without accentuating the understanding of the text.

- $\quad$ "Look and say" method: visual remembering (by memorising).

- Linguistic approach method: word reading observing the correspondence between letters and sounds.

- Entirety method: it is based on reading and writing as communicative actions (widely used in Latvia). The text is important in any reading process and it encourages activating of student's experience and involvement in the learning process.

- Language perception as an entirety method: while learning to read, it is necessary to choose interesting and meaningful texts. Learning to read is closely connected with the text to be read.

- Sentence forming method: learning to read uses word cards (cards with words written on them) that are changed depending on a particular text (Günther, 2002).

- Closed method: filling in the blanks with words from a sentence read before (Anspoka, 2008).

Learning strategies and techniques are individual for every student, however, teachers have to observe the teaching strategies, principles and techniques in the course of the teaching process:

1) students need to use various learning strategies,

2) teachers must use various teaching methods in order to supplement different teaching strategies when students are acquiring diverse knowledge,

3) students have to know and be able to use various learning strategies and techniques in order to better learn new material and be able to apply them in the further learning process consciously (learning strategies and techniques),

4) it is necessary to use strategy training in order to improve reading literacy and text comprehension. J. Anderson, M. Friend and D. Peterson have adopted several strategies for learning to read. Each of them is based on 
particular principles depending on what specific difficulties arise in the process of learning, for instance, regarding the comprehension of what has been read or the use of information.

Reading strategies to know how to read and understand if there are difficulties. READS method.

$\mathrm{R}$ (Review) review the title and the subtitle.

$\mathrm{E}$ (Examine) examine the letters and words printed in bold.

A (Ask) yourself "what am I expecting from these studies (this text)?"

$\mathrm{D}$ (Do) read!

S (Summarize) summarise the phrase in one or several sentences. (Friend, 1996, 54)

Strategies for reading and understanding literature:

CAPS:

C - What is the most important thing, the most explicit character in the text read (Character).

A - What is the most important aim of the story (Aim)?

$\mathrm{P}$ - What problem is discussed in the story (Problem)?

$\mathrm{S}$ - How is the problem solved (Solved)?

This method helps to organise the reading process. (Anderson, 1995, 72)

Strategy KWL is used in the teaching process and it is written on the board in order to define more accurately the learning material and to form a reference system during the studies, discussing what has been read or the learning material.

$\mathrm{K}$ (know) what do I know about this topic?

W (want) what do I wish to get to know?

L (learned) what have I learnt after an hour or after the class ? (Peterson, 2002, 439)

\section{Conclusions}

Acquiring of reading skills is a significant precondition not only for the learning process at school; it affects both one's professional career and participation in cultural, political and social life. Reading disorders become an obstacle in implementing one's plans later in life since a poor reader is often considered to be uneducated or under-developed (Nunes et al., 2009). This stereotype opinion is linked with the fact that reading disorders lead up to a low self-esteem and often cause problems related to behaviour etc. (Betz \& Breuniger, 1993).

During the pedagogical process of improving reading skills various methods and techniques are used with various types of activities and resources. The most important among them are READS and CAPS methods and the KWL strategy 
because each of them secures specific support in case of reading difficulties or disorders. Knowing individual resources of children as readers and using them appropriately in the reading process it is possible to increase the level of text comprehension.

It is essential to remember that all students want to and are able to learn the material. Reading can become a traumatic emotional experience if it is based on frequent failures. A slightest misunderstanding or intrusion into students' logics may cause emotional suffering.

\section{References}

1. Anderson, J.R (1995). Cognitive Psychology and Its Implications, $4^{\text {th }}$ Ed. New York: Freeman.

2. Anspoka, Z. (2008). Latviešu valodas didaktika. 1.-4. klase [Didactics of the Latvian Language. Form 1-4]. Rīga: RaKa, 474 Ipp. (in Latvian).

3. Artelt, C. (2001). Lesekompetenz: Textkompetenz und Ergebnisse. In: Baumert, J. (Hrg.) PISA (2000). Basiskompetenz von Schülerinnen und Schülern im internationalen Vergleich. Oplanden: Lesk+Budrich, S. 69-137.

4. Betz, D. \& Breuniger, H. (1993). Teufelskreis Lehrstörungen. Weinheim: Psychologie Verlags Union, S. 14-49.

5. Das, J. P. (1998). Dyslexia \& Reading Difficulties. An Interpretation for Teachers. Canada: IP Das Developmental Disabilities Centre, University of Alberta, Edmonston.

6. Davis, R. (1997). The Gift of Dyslexia: Why Some of the Smartest People Can't Read and How They Can Learn. Perigee Books.

7. Friend, M. \& Bursuk, W. (1996). Including Students with Special Needs: A Practical Guide for Classroom Teachers. Boston: Allyn and Bacon.

8. Günther, H. (2002). Psycholinguistische Lese- und Rechtschreibförderung. Göttingen: Huber, S. 11-25.

9. Hurrelmann, B., Hammer, M. und Nieß, F. (1993). Lesesozialisation. Gütersloh: Verlag Bertelsmann Stifftung, S. 65.

10. Kintsch, W. \& van Dijk, T. A. (1978). Towards a Model of Text Comprehension and Production. Psychological Review, Vol. 85, p. 363-394.

11. Lerner, J. W. (1997). Learning Disabilities: Theories, Diagnosis, and Teaching Strategies. Boston: Houghton Miffilin.

12. Lexikon der Psychologie: in fünf Bänden, Band 2: F bis L. Ed.: Gerd Wenniger (2001). Heidelberg; Berlin: Spectrum, Akademisches Verlag, p. 94.

13. Nunes, T., Bryant, P. (2009). Children's Reading and Spelling. Willey-Blackwell, A John Willey \& Sons, Ltd., Publication, p. 296.

14. Peterson, D. \& van der Wege, C. (2002). Guiding Children to be Strategic Readers. Phi Delta Kappan, p. 83, 437-440.

15. Plucker, J. A., Beghetto, R. A. \& Dow, G. T. (2004). Why isn't Creativity More Important to Educational Psychologists? Potencial Pitfalls and Future Directions in Creativity 
Research. Educational psychology, Vol. 39 (2), p. 83-96.

16. Rathus, S. A. (1988). Understanding Child Development. New York: Holt, Rineharet \& Winston, p. 85-97.

17. Rosser, R. (1994). Cognitive Development: Psychological and Biological perspectives. Boston: Allyn \& Bacon.

18. Skola visiem [School for Everyone]. (2002). Palīgs pedagogiem, psihologiem un vecākiem [Supplementary Aid for Teachers, Psychologists and Parents]. Rīga: SAC (in Latvian).

19. Tūbele, S. (2008). Disleksija vai lasišanas traucējumi [Dyslexia or Reading Disorders]. Rīga: RAKA, 161 lpp. (in Latvian).

20. Woolfolk, A. (2008). Pädagogische Psychologie. Pearson Studium, p. 67-394.

21. Корнев, А. Н. (2003). Нарушения чтения и письма у детей [Reading and Writing Disorders of Children]. Санкт-Петербург: Речь, 330 c.

22. www.pirls.bc.edu (Retrieved 15.09.2009.)

23. www.ppf.lu.lv (Retrieved 17.09.2009.)

24. Legasthenie und andere Wahrnehmungsstörungen. http://www.legasthenie.net/ index.php5?p=/legasthenie\#5. (Retrieved 15.09.2009.)

Asoc. prof., Dr. psych. Tija Zïriṇa

Riga Teacher Training and Educational Management Academy

Address: Imantas 7. linija 1, Riga, Latvia, LV-1083

Tel.: + 37167808122

E-mail: tija.zirina@rpiva.Iv

Lecturer, Mg. psych. Anda Kauliṇa

Riga Teacher Training and Educational Management Academy

Address: Imantas 7. linija 1, Riga, Latvia, LV-1083

Tel.: + 37167808109

E-mail: andakaulina@inbox.Iv 